\title{
Economic and Environmental Benefits of Replacing Diesel Pumps with Solar Irrigation Pumps in Jaipur, Rajasthan
}

\author{
Yash Gautam*, O.P. Singh and P.K. Singh \\ Department of Agricultural Economics, Institute of Agricultural Sciences, BHU, Varanasi, India \\ *Corresponding author: yashgautam37@gmail.com (ORCID ID: 0000-0003-1142-3511)
}

Paper No. 870

Received: $13-07-2020$

Revised: $14-10-2020$

Accepted: 28-11-2020

\begin{abstract}
With the increase in population, urbanization, and development in India, the energy demand has increased in recent years. One of the main consumers of energy is the agricultural sector. Agriculture in India saw significant development regarding production and technology. India heavily relies on the energy derived from fossil fuels for driving its engine of development. Currently, India is the third-largest Greenhouse gas emitter in the world after China and the USA. So, for continued development along with reducing GHG, India needs to switch its source of energy from fossil fuels to renewable sources. This paper uses primary data to analyze the economic and environmental benefits of solar irrigation pumps in terms of savings on fuel and reduction in carbon emission.
\end{abstract}

Highlights

( Savings on diesel fuel by replacing diesel irrigation pump by solar irrigation pump.

- Reduction in carbon dioxide and carbon emission by replacing diesel irrigation pump.

o Carbon credits generated by replacing diesel irrigation pump.

Keywords: Carbon emission, Solar pump, Carbon credits, Environment benefits

Agriculture sector has an important hand in shaping the Indian economy. Agriculture, with its allied sectors, is unquestionably the largest livelihood provider in India, more so in the vast rural areas. It not only provides food and employment but also helps in earning foreign exchange, capital formation, supply raw material to agro-based industries, absorb surplus-labor, and influences internal and external trade of the country. Indian agriculture has a cost advantage in several agricultural commodities in the export sector because of low labor costs and self-sufficiency in input supply.

With the passage of time, agriculture such as all other sectors, has seen tremendous growth in production and technology. These changes were necessary, especially in India's context because of the large size of the population. For a population so large, normal agriculture production is not sufficient. Past experiences also helped us in making our country food sufficient. After the infamous Bengal famine of 1943 in which approximately 4 million people died of hunger. There was a need to increase food production to make the country self-sufficient in food. But the real breakthrough came in the 1960s with the introduction of the green revolution in India. However, this revolution made India -sufficient in food and one of the major exporters of food grains but at the cost of environmental degradation like soil health depletion, water scarcity, etc. In many areas, the water table has been

How to cite this article: Gautam, Y., Singh, O.P. and Singh, P.K. 2020. Economic and Environmental Benefits of Replacing Diesel Pumps with Solar Irrigation Pumps in Jaipur, Rajasthan. IJAEB, 13(4): 469-474.

Source of Support: None; Conflict of Interest: None 
contaminated by the percolation of water mixed agrochemicals. It is important because, with any sector's development, one has to keep in mind the environmental aspect. Any development sustains in the long-term only when it goes hand-in-hand with the environment.

With the increase in population, ,urbanization, and development in India, the demand for energy has increased in recent years. One of the main consumers of energy is the agricultural sector. Agriculture in India saw significant development regarding production and technology. Today, most of the agricultural activities are mechanized to a large extent, and they require fuel to run. There is no doubt that by the introduction of new technology, agricultural production, productivity, and resource use efficiency has increased. Four billion liters of diesel and around 85 million tons of coal per annum get used up to support water pumping for irrigation in India. If one million diesel pumps were replaced with solar pumps, then it would result in diesel use mitigation of approximately nine billion liters over the life cycle of solar pumps. It would reduce carbon dioxide emission up to 25.3 million tonnes. Foreign exchange savings of USD \$ 300 million per annum on diesel imports for replacement of one million diesel pumps translating into forex savings of USD $\$ 4.5$ billion over pump life (KPMG 2014).

India heavily relies on the energy derived from fossil fuels for driving its engine of development. Around 69.5 percent of the total power is generated by thermal power plants (MoP, 2020). In India, electricity generated by burning fossil fuels contributes 37.8 percent of the total greenhouse gasses released in the atmosphere (GoI 2016). Burning fossil fuels increases carbon-dioxide emission, which is a major contributor to the climate change crisis today (Schock et al. 2007). In 2016, the World Health Organization (WHO) released a report in which 11 Indian cities have occupied positions in the list of top 25 polluted cities of the world (WHO 2017). Currently, India is the thirdlargest Greenhouse gas emitter in the world after China and the USA.

Unquestionably, neither India's energy demand will decrease, nor the development process can be stopped. So, for continued development at the current pace along with reducing the GHG, India needs to switch its source of energy from fossil fuels to renewable sources like Solar, Wind, etc. Renewable energy sources are capable of solving the problem of sustainable development associated with fossil fuel-based power plants as these energy sources are unlimited, eco-friendly, and provide energy with negligible emissions of air pollutants and greenhouse gases (Singal 2007). It is clearly feasible to replace the current fossil fuel infrastructure with solar power and other renewable, and reduce $\mathrm{CO}_{2}$ emissions to a level commensurate with the most aggressive climate change goal (Fthenakis et al. 2009). India has the fourth-highest installed wind power capacity in the world, with a total installed capacity of $35.62 \mathrm{GW}$.

To achieve a sustainable development path that simultaneously advances economic and environmental objectives, the National Action Plan for Climate Change (NAPCC) was launched on $30^{\text {th }}$ June 2008 in India. The NAPCC identifies measures that will promote our development objectives while providing benefits simultaneously for addressing climate change effectively. National Solar Mission, which was one of the eight key National Mission's which comprise India's NAPCC, was launched aiming to focus on an enabling environment for solar technology penetration in the country both at a centralized and decentralized level. In 201819, the government announced Kisan Urja Suraksha Evam Utthaan Mahabhiyan (KUSUM) Scheme. Under this scheme, farmers could purchase solar irrigation pumps at subsidized rates. The government will also provide an incentive to DISCOMS for purchasing additional energy generated by the farmers, thereby augmenting their income.

The highest annual global radiation of $\geq 2400 \mathrm{kWh} /$ $\mathrm{m}^{2}$ is received in Rajasthan and northern Gujarat. Rajasthan receives solar radiation of $6.0-7.0 \mathrm{kWh} /$ $\mathrm{m}^{2}$. In western areas like Thar Desert, dry spell it may extend up to 345-355 days as rains occur only for 10.4-20.5 days in a year (Meena et al. 2014).

With the implementation of several policy and subsidy schemes, solar irrigation pumps' adoption has become an attractive investment. Adoption of solar irrigation pump has been increasing in Rajasthan at a faster rate.

\section{Methodology}

Following study was conducted using primary data. Data was collected with the help of pre-tested survey 
schedule. State Rajasthan was selected because it receives the highest annual global radiation in India and the installation of solar irrigation pumps is maximum among all states. District Jaipur was selected because the number of solar irrigation pumps installed was maximum in the district. Respondents were selected using the snowball method of sampling. Respondents included farmers who were using $14 \mathrm{HP}$ diesel pump for irrigation but later replaced it with solar irrigation pump. To examine the economic benefits of solar irrigation pumps, the amount spent on diesel fuel used for running 14 diesel pump was calculated. After the adoption of solar irrigation pump, the farmer didn't purchase diesel, so the expenditure on diesel was saved, which was the economic benefit.

Environmental benefit realized by the adoption of solar irrigation pumps was the reduction in carbon emissions. To find out the reduction in carbon emissions, first of all diesel saving on irrigation were quantified with the help of the following relation:

1 litre diesel $=2.6 \mathrm{~kg} \mathrm{CO}_{2}$ emission (Jat et al. 2006)

$1 \mathrm{~kg} \mathrm{CO}=0.27 \mathrm{~kg}$ carbon (Paustian et al. 2006)

\section{RESULTS AND DISCUSSION}

\section{(a) Economic benefits of solar irrigation pumps}

In the study area, the average area under groundnut, bajra, wheat, and barley was $0.7 \mathrm{Ha}, 0.99 \mathrm{Ha}, 1 \mathrm{Ha}$, and $0.41 \mathrm{Ha}$. Diesel consumption for irrigating the total area of wheat, barley, bajra, and groundnut crops by using $14 \mathrm{HP}$ diesel pumps is presented in Table 1. A 14 HP diesel pump took on an average eight hours to irrigate one-hectare area. Average rate of diesel consumption of the $14 \mathrm{HP}$ diesel irrigation pump was estimated to be three liters per hour, and cost of diesel during the study period was estimated to be ₹ 81.99 per liter.
12 irrigations were provided by the respondent farmers for groundnut crops in the study area. The area allocated by the sample farmers under groundnut cultivation was estimated to be 0.70 hectares per farm. So, the total diesel requirement for irrigating 0.70 hectares of groundnut in the study area was estimated to be 201.60 liters. Hence, the total amount spent by the farmers on diesel used for irrigating groundnut crop at the rate of ₹ 81.99 per liter was ₹ 16,529.18 (See Table 1).

In the case of bajra, sample farmers were providing three irrigations during the crop period. The total area devoted by the sample farmers in the study area for bajra cultivation was estimated to be 0.99 hectares per farm. Therefore, farmers had to burn about 71.28 liters of diesel to irrigated 0.99 hectares of bajra by using $14 \mathrm{HP}$ diesel pumps during the growing season of the crop. So, the total expenditure on diesel used for irrigating bajra crop was ₹ 5,844.25 (See Table 1).

Total area allocated by the sample farmers in the study area for wheat cultivation was estimated to be 1 hectare per farm. Sample farmers were irrigating wheat crop six times during a complete life-cycle and providing one irrigation to the wheat crop, requires to run diesel pump eight hours. So, the total diesel consumption to irrigate 1-hectare area of the wheat crop was 144.00 liters. Hence, the total cost of diesel used for wheat irrigation at the rate of ₹ 81.99 per liter was ₹ 11,806.56 (See Table 1).

Sample farmers were providing an average of three irrigation to barley crops during the season. The total area allocated by the sample farmers for barley cultivation was found to be 0.41 hectares per farm. So, 29.52 liters of diesel were required to irrigate 0.41 hectares area of barley crop by $14 \mathrm{HP}$ diesel pump. Therefore, the total cost of diesel at the rate of ₹ 81.99 per liter was equal to ₹ 2,420.34 for barley crop (See Table 1).

Table 1: Diesel consumption by a $14 \mathrm{HP}$ diesel irrigation pump per farm

\begin{tabular}{llllllll}
\hline S1. No. Crop & $\begin{array}{l}\text { Area per } \\
\text { farm (Ha) }\end{array}$ & $\begin{array}{l}\text { Number of } \\
\text { irrigation }\end{array}$ & $\begin{array}{l}\text { Time required } \\
\text { per irrigation } \\
\text { (Hrs/Ha) }\end{array}$ & $\begin{array}{l}\text { Diesel } \\
\text { consumption per } \\
\text { hectare (L/Ha) }\end{array}$ & $\begin{array}{l}\text { Diesel } \\
\text { consumption per diesel @ ₹ 81.99 per } \\
\text { farm (Litres) }\end{array}$ & $\begin{array}{l}\text { Total Cost of } \\
\text { litre }\end{array}$ \\
\hline 1 & Groundnut & 0.70 & 12 & 8 & 288 & 201.60 & $16,529.18$ \\
2 & Bajra & 0.99 & 3 & 8 & 72 & 71.28 & $5,844.25$ \\
3 & Wheat & 1.00 & 6 & 8 & 144 & 144 & $1,806.56$ \\
4 & Barley & 0.41 & 3 & 8 & 72 & 29.52 & $2,420.34$ \\
\hline $\mathbf{5}$ & Total & & & & $\mathbf{5 7 6}$ & $\mathbf{4 4 6 . 4 0}$ & $\mathbf{3 6 , 6 0 0 . 3 4}$ \\
\hline
\end{tabular}


It was clear from the above results that if $14 \mathrm{HP}$ diesel irrigation pump was used to irrigate 0.70 hectares of groundnut, 0.99 hectares of bajra, 1.00 hectare of wheat, and 0.41 hectares of barley, then the total consumption of diesel was 446.40 liters per farm. This means a farmer had to spend ₹ 36,600.34 to irrigate their farm in a year. Since the respondents were not using diesel irrigation pumps anymore, so, there was no consumption of diesel for irrigation purposes. Thus, the savings on diesel for each farmer would be equal to ₹ $36,600.34$. Also, it was concluded that by using solar irrigation pumps instead of diesel irrigation pumps for irrigation purposes 446.40 liters of diesel was saved per farm during a year (See Table 1).

\section{(b) Environmental benefits of solar irrigation pumps}

Environmental benefits realized by the adoption of solar irrigation pump was the reduction in carbon emissions due to running of diesel pump for irrigation purpose. To estimate the reduction in carbon emissions, first of all, diesel savings on irrigation were converted into the amount of carbon dioxide (in Kilograms), and then the amount of carbon dioxide was converted into the amount of Carbon.

Table 2 shows diesel consumption, carbon dioxide, and carbon emission from per hectare wheat, barley, bajra, and groundnut by $14 \mathrm{HP}$ diesel irrigation pump.

In the case of the groundnut crop, irrigating one hectare for one season consumed 288 liters of diesel. Upon burning this much diesel, $748.8 \mathrm{Kg}$ of carbon dioxide was released in the atmosphere, thereby emitting $202.18 \mathrm{Kg}$ of carbon into the atmosphere from groundnut alone (See Table 2).
Three irrigations of bajra in one-hectare area in one season consumed 72 liters of diesel. It produced 187.2 Kg of carbon dioxide converting into $50.54 \mathrm{Kg}$ of carbon in the atmosphere (See Table 2).

Irrigating one hectare of wheat by $14 \mathrm{HP}$ diesel irrigation pump required 144 liters of diesel. It produced $374.4 \mathrm{~kg}$ of carbon dioxide, thereby emitting $101.09 \mathrm{Kg}$ of carbon in the atmosphere.

Barley crop consumed 72 liters of diesel per hectare per season when irrigated by $14 \mathrm{HP}$ diesel pump. 72 liters of diesel produced $187.2 \mathrm{Kg}$ of carbon dioxide and hence emitted $50.54 \mathrm{Kg}$ of carbon into the atmosphere (See Table 2).

From Table 2, it was observed that if 14 HP diesel irrigation pump was used to irrigate 1 hectare each of groundnut, bajra, wheat, and barley then it would consume 576 liters of diesel, which would release $1497.6 \mathrm{Kg}$ of carbon dioxide in the atmosphere. Hence, the total carbon emission would have been $404.35 \mathrm{Kg}$.

\section{Computation of carbon emissions from total area irrigated by diesel pumps of selected crops in Rajasthan}

Table 3 shows diesel consumption, carbon dioxide, and carbon emissions, when the total area of groundnut, bajra, wheat, and barley, which was irrigated by diesel pumps of different HP in Rajasthan, was assumed to be irrigated by $14 \mathrm{HP}$ diesel irrigation pumps.

In the case of groundnut, the total area under crops was $1,65,545.3$ hectares in Rajasthan. Irrigating $1,65,545.3$ hectares area by $14 \mathrm{HP}$ diesel pumps would require 47.68 million liters of diesel as fuel. This would produce 1,23,960.35 tonnes of carbon dioxide leading to the emission of 33,469.30 tonnes of carbon in the atmosphere per year (See Table 3).

Table 2: Diesel consumption, carbon dioxide and carbon emission from one hectare of each major crop irrigated by 14 HP diesel pump

\begin{tabular}{lllll}
\hline S1. No. & Crop & $\begin{array}{l}\text { Diesel consumption } \\
(\text { Litres/Ha) }\end{array}$ & Amount of $\mathbf{C O}_{\mathbf{2}}(\mathbf{K g} / \mathbf{h a})$ & Carbon emission $(\mathrm{Kg} / \mathrm{Ha})$ \\
\hline 1 & Groundnut & 288 & 748.8 & 202.18 \\
2 & Bajra & 72 & 187.2 & 50.54 \\
3 & Wheat & 144 & 374.4 & 101.09 \\
4 & Barley & 72 & 187.2 & 50.54 \\
\hline & Total & $\mathbf{5 7 6}$ & $\mathbf{1 4 9 7 . 6}$ & $\mathbf{4 0 4 . 3 5}$ \\
\hline
\end{tabular}


Table 3: Diesel consumption, carbon dioxide and carbon emission from the total area irrigated by 14 HP diesel pumps of selected crops

\begin{tabular}{llllll}
\hline S1. No. & Crop & $\begin{array}{l}\text { Area irrigated by } \\
\text { diesel pump } \mathbf{~ H a )}\end{array}$ & $\begin{array}{l}\text { Diesel consumption } \\
\text { (Million Litres) }\end{array}$ & $\begin{array}{l}\text { Carbon dioxide } \\
\text { produced (Tonnes) }\end{array}$ & $\begin{array}{l}\text { Carbon emission } \\
\text { (Tonnes) }\end{array}$ \\
\hline 1 & Groundnut & $1,65,545.3$ & 47.68 & $1,23,960.35$ & $33,469.30$ \\
2 & Bajra & $54,620.1$ & 3.93 & $10,224.87$ & $2,760.72$ \\
3 & Wheat & $8,80,779.3$ & 126.83 & $3,29,763.77$ & $89,036.21$ \\
4 & Barley & $78,976.8$ & 5.69 & $14,784.47$ & $3,991.81$ \\
\hline & Total & $\mathbf{1 1 , 7 9 , 9 2 1 . 5 5}$ & $\mathbf{1 8 4 . 1 3}$ & $\mathbf{4 , 7 8 , 7 3 3 . 4 6}$ & $\mathbf{1 , 2 9 , 2 5 8 . 0 4}$ \\
\hline
\end{tabular}

Table 4: Carbon credit generated by replacing 14 HP diesel pump with solar irrigation pump

\begin{tabular}{lllllll}
\hline S1. No. & Crop & $\begin{array}{l}\text { Area irrigated by } \\
\text { diesel pump (Ha) }\end{array}$ & $\begin{array}{l}\text { Carbon di } \\
\text { oxide emission } \\
\text { (tonnes) }\end{array}$ & $\begin{array}{l}\text { Carbon } \\
\text { credit }^{*}\end{array}$ & $\begin{array}{l}\text { Carbon price @ } \\
\text { USD 40 }\end{array}$ & $\begin{array}{l}\text { Carbon price @ USD } \\
\mathbf{8 0}\end{array}$ \\
\hline 1 & Groundnut & $1,65,545.3$ & $1,23,960.35$ & $1,23,960.35$ & $4,958,414.00$ & $9,916,828.00$ \\
2 & Bajra & $54,620.1$ & $10,224.87$ & $10,224.87$ & $4,08,994.80$ & $8,17,989.60$ \\
3 & Wheat & $8,80,779.3$ & $3,29,763.77$ & $3,29,763.77$ & $13,190,550.8$ & $26,381,101.6$ \\
4 & Barley & $78,976.8$ & $14,784.47$ & $14,784.47$ & $5,91,378.80$ & $1,182,757.60$ \\
\hline & Total & $\mathbf{1 1 , 7 9 , 9 2 1 . 5 5}$ & $\mathbf{4 , 7 8 , 7 3 3 . 4 6}$ & $\mathbf{4 , 7 8 , 7 3 3 . 4 6}$ & $\mathbf{1 9 , 1 4 9 , 3 3 8 . 4 0}$ & $\mathbf{3 8 , 2 9 8 , 6 7 6 . 8 0}$ \\
\hline
\end{tabular}

* 1 carbon credit $=1$ ton carbon dioxide.

Total area under bajra cultivation in the state was $54,620.1$ hectares irrigated by a diesel pump. By using $14 \mathrm{HP}$ pumps to irrigate this area, diesel consumption would be 3.93 million liters. Using 3.93 million liters of diesel as fuel would produce $10,224.87$ tonnes of carbon dioxide, thereby emitting $2,760.72$ tonnes of carbon in the air per year (See Table 3).

Total area of wheat irrigated by diesel pumps was 880779.3 hectares in Rajasthan. If this area was irrigated by $14 \mathrm{HP}$ diesel pumps, then it would consume 126.83 million liters of diesel. It would produce $3,29,763.77$ tonnes of carbon dioxide leading to the emission of 89,036 tonnes of carbon in the atmosphere per year (See Table 3).

Irrigating 78,976.8 hectares area of barley by $14 \mathrm{HP}$ pumps would consume 5.69 million liters of diesel, which would produce $14,784.47$ tonnes of carbon dioxide. This huge amount of carbon dioxide would emit 3,991.81 tonnes of carbon in the atmosphere per year (See Table 3).

From Table 3, it was observed that when a total area of 11,79,921.55 hectares of groundnut, bajra, wheat, and barley was irrigated using $14 \mathrm{HP}$ diesel pumps, then it would consume 184.13 million liters of diesel to run the pump. This would produce 4,78,733.46 tonnes of carbon dioxide, thereby emitting 1,29,258.04 tonnes of carbon in the atmosphere per year.

During the $22^{\text {nd }}$ Conference of the Parties of the United Nations Framework Convention on Climate Change (UNFCCC) held in 2016, the High-Level Commission on Carbon Prices suggested that the carbon prices of at least USD 40 to USD 80 per tonne carbon dioxide by 2020 and USD 50 to 100 per tonne of carbon dioxide by 2030 are required to effectively reduce carbon emissions to meet the temperature goals as decided in the Paris Agreement (Stiglitz et al. 2017).

Table 4 shows the carbon credits that could be generated by replacing $14 \mathrm{HP}$ diesel pumps with solar irrigation pumps in the selected cropping system in Rajasthan. Total area irrigated by the 14 HP diesel pump in Rajasthan was 11,79,921.55 hectares. We assumed that if the same area would have been irrigated by a solar irrigation system, then it would generate carbon credit equal to 4,78,733.46. If this carbon credit was sold in the international market as suggested by High-Level Commission on Carbon Prices at the rate of USD 40 or USD 80 then it would generate revenue equal to USD 19.15 to USD 38.30 million, respectively. 


\section{CONCLUSION}

From the findings of the study that it was observed that when $14 \mathrm{HP}$ diesel irrigation pump was used to irrigate one hectare each of groundnut, bajra, wheat, and barley, then it consumed 576 liters of diesel, which released $1497.6 \mathrm{Kg}$ of carbon dioxide in the atmosphere. Hence, the total carbon emission was $404.35 \mathrm{Kg} / \mathrm{Ha}$.

If the total area of 11,79,921.55 hectares of groundnut, bajra, wheat, and barley was irrigated using $14 \mathrm{HP}$ diesel irrigation pumps, then it would consume 184.13 million liters of diesel to run the diesel pump. This would produce 4,78,733.46 tonnes of carbon dioxide, thereby emitting 1,29,258.04 tonnes of carbon in the atmosphere per year. India could benefit significantly in terms of carbon credit in the international market if it replaced as many diesel irrigation pumps with solar irrigation pumps.

\section{REFERENCES}

Fthenakis, V., Mason, J.E. and Zweibel, K. 2009. The technical, geographical, and economic feasibility for solar energy to supply the energy needs of the US. Energy policy, 37(2): 387-399.

Jat, M.L., Sharma, S.K. and Singh, K.K. 2006. Conservation agriculture for sustainable farming in India. Paper presentation in Winter School Training at Department of Agronomy, TNAU, Coimbatore, January, 21, 2006.

Klynveld Peat Marwick Goerdeler. 2014. Feasibility analysis for solar agricultural water pumps in India. KPMG Advisory Services Private Limited. https://shaktifoundation.in/ wp-content/uploads/2014/02/feasibility-analysis-forsolar-High-Res-1.pdf [Last Accessed on 2020, January 14]

Meena R.S., Sharma D. and Rathore R. 2014. The most promising solar hot spots in India development and policy: the Thar desert of Rajasthan. Int. J. Eng. Res., 3(1): 74-79.
Ministry of Environment, Forest and Climate Change. 2016. Report of Indian network for climate change assessment. Government of India.

Ministry of Power. 2020. Power sector at a glance all India; 2016. Government of India. https://powermin.nic.in/content/ power-sector-glance-all-india [Last Accessed on 2020, November 04].

National Institution for Transforming India. 2017. Doubling Farmers' Income: Rationale, Strategy, Prospects and Action Plan. NITI Policy Paper No. 1/2017. National Institute for Transformation India, Government of India, New Delhi. http://niti.gov.in/writereaddata/files/document_ publication/ DOUBLING \%20FARMERS\%20INCOME. pdf [Last Accessed on 2020, November 02].

Paustian, K., Antle, M., Sheehan, J. and Eldor, P. 2006. Agriculture's Role in Greenhouse Gas Mitigation. Washington, DC: Pew Center on Global Climate Change. http:// www.fao.org/fileadmin/user_upload/rome2007/docs/ Agriculture_Role_in_Greenhouse_Gas_Mitigation. pdf[Last Accessed on 2020, August 13].

Schock, R.N., Sims, R.E.H., Adegbululgbe, A., Fenhann, J., Konstantinaviciute, I., Moomaw, W., Nimir, H.B., Schlamadinger, B., Torres-Martínez, J., Turner, C., Uchiyama, Y., Vuori, S., Wamukonya, N. and Zhang, X. 2007. Energy supply. In: Climate Change 2007: Mitigation. Contribution of Working Group III to the Fourth Assessment Report of the Intergovernmental Panel on Climate Change. Metz, B.; Davidson, O.R.; Bosch, P.R.; Dave, R.; Meyer, L.A. (eds). (pp. 252-322). Cambridge University Press.

Singal, S.K. 2007. Review of augmentation of energy needs using renewable energy sources in India. Renewable and sustainable energy reviews, 11(7): 1607-1615.

Stiglitz, J.E., Stern, N., Duan, M., Edenhofer, O., Giraud, G., Heal, G. Rovere, E.L., Morris, A., Moyer, E., Pangestu, M., Sokona, Y., Winkler, H. and Shukla, P.R. 2017. Report of the high-level commission on carbon prices, pp. 3.

World Health Organization. Exposure to ambient air pollution; 2017. Retrieved from: “http://www.who.int/ gho/phe/outdoor_air_pollution/exposure/en/". [Last Accessed on 2020 August 5]. 